\title{
INTERACTION BETWEEN FINANCIAL SECTOR DEVELOPMENT AND MICROFINANCE INSTITUTION (MFIs) PERFORMANCE IN SOUTHEAST ASIA
}

\author{
Chaerani Nisa ${ }^{1}$, Tia Ichwani ${ }^{2}$, Nurwidhi Arief Sutoyo ${ }^{3}$ \\ 1,2,3 Pancasila University, Jakarta, Indonesia \\ Correspondence email: ${ }^{1}$ chaerani.nisa@univpancasila.ac.id
}

\begin{abstract}
This study aims to examine the effect of financial sector development on the financial and social performance of MFIs. This research is a quantitative research. The population is all MFls listed on MixMarket. This study uses purposive sampling with MFI criteria that have complete data needed from 1999 to 2019. This study uses panel data because it uses MFIs from nine countries but in different years. Data collected using data from MixMarket with a research period between 1999 and 2019. The results show that the revival of the financial sector has a negative impact on the independence of MFIs. On the other hand, progress in the financial sector also has a negative impact on MFIs for the poor. This condition indicates that there is competition between the two, as developments in the financial sector have a negative impact on the MFI's ability to generate higher incomes. The implication of this finding is that policy makers are more careful in determining the operational reach of the traditional financial sector and MFIs.
\end{abstract}

Keywords: financial performance; financial sector development; funding; microfinance institution; social performance

Penelitian ini bertujuan untuk menguji pengaruh pengembangan sektor keuangan terhadap kinerja keuangan dan sosial LKM. Penelitian ini adalah penelitian kuantitatif. Populasinya adalah semua LKM yang terdaftar di MixMarket. Penelitian ini menggunakan purposive sampling dengan kriteria LKM yang memiliki kelengkapan data yang dibutuhkan dari tahun 1999 hingga 2019. Penelitian ini menggunakan data panel yang karena menggunakan LKM dari sembilan negara tetapi berbeda tahun. Data penelitian dikumpulkan dengan menggunakan data dari MixMarket dengan periode penelitian antara 1999 hingga 2019. Hasil penelitian menunjukkan bahwa kebangkitan sektor keuangan berdampak negatif terhadap independensi LKM. Di sisi lain, kemajuan sektor keuangan juga berdampak negatif pada jangkauan LKM kepada masyarakat miskin. Kondisi ini menunjukkan adanya persaingan di antara keduanya, karena perkembangan sektor keuangan berdampak negatif pada kemampuan LKM untuk menghasilkan pendapatan yang lebih tinggi. Implikasi dari temuan ini adalah pembuat kebijakan lebih berhati-hati dalam menentukan jangkauan operasional sektor keuangan tradisional dan LKM.

Kata kunci: kinerja keuangan; kinerja sosial; lembaga keuangan mikro; pendanaan; pengembangan sektor keuangan

\section{ARTICLE INFORMATION}

Article History: submitted: January 27, 2021; revised: April 26, 2021; accepted: Juny 15, 2021

JEL Classification: M30, M38

How to Cite: Nisa, C., Ichwani, T., \& Sutoyo, N. A. (2021). Interaction Between Financial Sector Development and Microfinance Institution (MFIs) Performance in Southeast Asia. JIMFE (Jurnal IImiah Manajemen Fakultas Ekonomi), 7(1), 51-62. https://doi.org/10.34203/jimfe.v7i1.3069 


\section{INTRODUCTION}

Microfinance Institution (MFI) is a financial institution that specifically offers financing to the poor or small businesses that generally do not have direct access to banking. This is due to the absence of collateral or the relatively small need for MFIs so that it is no longer profitable for banks to channel loans to them (Cull et al., 2009). In the last two decades, MFI has shown a rapid development with a fairly high level of success, especially in developing countries. MFI has become one of the sectors that supports the creation of small-scale businesses that have an impact on improving the welfare of the poor as well as contributing to poverty alleviation. According to Mersland \& Øystein Strøm (2009), millions of people who were previously marginalized from financial facilities have gained access to financial services and this condition cannot be separated from the interference of MFIs.

In support of this view, the United Nations designated 2005 as the international year of microcredit. In 2006, Muhammad Yunus, one of the world's micro credit figures with an institution called the Grameen Foundation, received the Nobel Peace Prize for his dedication to alleviating poverty through microcredit to marginalized communities. The importance of MFI's existence is also reflected in the facts of existing achievements. In 2012, MFI served more than 91 million customers worldwide with total loans reaching USD 81,5 billion. Meanwhile, Reed et al. (2015) stated that there are 211 million poor people who have been served by MFIs, most of which are people who are at extreme poverty levels.

Given the importance of MFIs, several studies have tried to examine the factors that support the sustainability of MFIs so that MFIs can develop and continue to serve the poor. Many literature call these two objective as social and financial performance of MFI (Hermes \& Hudon, 2018). Social performance related to the ability of MFI to reach more poor people while financial performance is the capability to sustain without having to depend on donor or subsidies.

During its journey, MFIs often face many obstacles, including problems with the resources or competition from other financial institutions that have better resources, such as commercial banks or financial technology companies. In the line of research on MFIs, the survival of MFIs as institutions is often seen as inconsistent with its mission to serve the poor. In other words, there is often a trade-off between the two. The trade-off condition occurs when an MFI wants to achieve financial sustainability or independence, which means that it is not dependent on subsidies, the MFI must give up its reach to the poor. In this situation, MFIs can no longer serve the poor because the costs incurred to serve them are quite large, thereby reducing the profits that MFIs can use to sustain their operations.

Therefore, environmental conditions that are suitable for the development of MFIs businesses are very much needed so that MFIs can continue to serve the poor and promote poverty alleviation in various countries. Several studies on MFI analyses specifically the conditions that are most suitable for MFIs to develop optimally. One of the observations is the development of the financial sector in the country. Observations about the development of the financial sector in a country are often included in observations about the macroeconomic conditions in that country. Macroeconomic conditions often determine whether an MFI will be successful or will fail. The success of MFIs is important because of the much attention and funding that has been channelled to MFIs over the last few decades.

However, the success rate of MFIs varies under each condition. Some of them failed while some of them grew bigger and managed to reach millions of customers (Ahlin et al., 2011). In this context, it is necessary to evaluate the condition of the MFI. Furthermore, various studies have tried to find out, the key to the success of a successful MFI that grows and develops well. Thus, our first question is that what is the ideal conditions for MFI to develop well.

Financial systems exist because they help allocate resources in various places and periods of time. The advance in financial sector can be explained as the existence of various financial instruments and institutions, as well as their contribution to increasing the efficiency of allocation of scarce resources. 
Various literatures specifically explain the positive impact of financial sector development on economic growth (Evans et al., 2019; Rahman et al., 2020). In general, the view that exists among academics is that financial sector development improves macroeconomic performance because the financial sector helps allocate scarce resources to the most profitable and most efficient projects. Hence, developed financial institutions and instruments create an enabling environment for the growth of the economy.

The next question is whether the progress of the financial sector has a positive impact on the performance of MFIs? Hermes et al. (2009) describe three mechanisms for advancing the financial sector that have a positive impact on MFI performance. The first mechanism is that the progress of the financial sector means an increase in the number of commercial banks and / or an increase in the number of services offered by commercial banks in the micro credit segment. The increase in the number of commercial banks and the activities they carry out is likely to have an impact on increasing competition for borrowers among microcredit actors, including in MFIs. In some countries, commercial banks have also plunged into offering loans to the micro credit segment because of the benefits provided to this segment (Xu et al., 2016). Several studies have shown that commercial banks that offer microcredit have better performance than commercial banks that are not involved in this segment (Deb, 2018). Increasing competition in getting borrowers will encourage MFIs to be more efficient in running their business so that in the end it will reduce costs and MFI's performance will improve.

Meanwhile, the argument for the next positive relationship is that progress in the financial sector can encourage the creation of a spill over effect. Commercial banks have advanced technology that encourages them to operate more efficiently where this technology is not yet owned by MFIs. This latest banking technology is being copied by MFIs, which can further increase their efficiency. The presence of commercial banks also increases the number of educated workforces. These educated workforces can become a source of new workforce at MFIs where they then apply these skills to the MFI sector (Vanroose \& D'Espallier, 2013).

Third, advances in the financial sector in the form of better financial sector regulation and supervision could also help increase the efficiency of MFIs. The increasing role of financial institutions has the potential to trigger the government to improve the existing regulations or supervisory systems. Improvements to the system include application to MFIs and financial practices that apply to MFIs. The consequence is that increased regulation and supervision on MFI activities will further contribute to improving the efficiency level of MFIs. This line of argument is supported, among other things, by findings that stated that the response from regulators to MFI developments varies depending on the development of the financial sector as a whole and the financial reforms that are being carried out by the country.

The main argument for the negative relationship between commercial banks and MFIs is also related to competition. However, the fundamental difference is how competition impacts MFI operations. In the positive relationship above, the existence of competition between MFIs and commercial banks encourages MFIs to practice more efficiently which in turn will improve MFI performance (Hermes et al., 2011). On the other hand, competition between MFIs and commercial banks can also have a negative impact on MFI performance. Among other things, this can be seen if the competition that occurs between MFIs encourages MFI borrowers to switch to commercial banks. This can happen because commercial banks offer lower interest rates or larger loan amounts.

In addition, the existence of competition also increases the likelihood of worsening returns from MFI customers. This condition occurs because MFI borrowers get loan offers in more than one place, as a result the borrower takes both loans and ultimately affects the repayment ability of the MFI borrower. If this is continued, this condition can endanger the borrower's finances due to an increase in the debt ratio of the borrower to the level of ability to repay. Furthermore, overall MFI performance will also 
deteriorate. Hermes \& Hudon (2018) also shows other impacts of financial sector progress on MFI performance. According to Hermes \& Hudon (2018), the development of the financial sector also increases MFIs' access to financial services. One example is that MFIs can get financing from commercial banks in the form of linkage programs (Hamada, 2010). Hamada (2010) found that financing from commercial banks increases the financing channelled by BPRs to the poor.

MFIs in Asia have different characteristics compared to MFIs in other regions such as Latin America or Africa (Iqbal et al., 2019). MFIs in Asia are generally distinguished from institutional missions which are mainly related to the economic development of communities so that they place more emphasis on social outreach to marginalized communities. The microfinance sector in Asia was established to provide financial services to the poor who have been marginalized from conventional financial services. MFIs mostly grow in Asia, where most of the world's population resides in this region, with a high number of people living below the poverty line. In 2010,63\% of the total population of the world's extremely poor were in South Asia (507 million) and East Asia and the Pacific (246 million). This high population indicates the great need for MFI services which this condition has often been neglected. Therefore, this study focuses on the Asian region because specific observations on it can provide insights into factors that can improve MFI performance and ultimately improve services to the poor.

To the best of the authors' knowledge, research dedicated to investigating relationship between financial sector development and MFIs performance in Southeast Asia has not been reported elsewhere. Hence, this research presents an empirical study that investigate this issue.

\section{LITERATURE REVIEW AND RESEARCH DEVELOPMENT}

Existing research has often ignored the conditions of the country where MFIs are located (Vanroose \& D'Espallier, 2013). Most of the studies investigate MFIs' internal condition, such as governance or other management issues. Only some of them give emphasizes on macroeconomic condition. Gonzalez (2011) is one of the examples. Gonzalez (2011) find shocks in macroeconomic conditions did not have a significant impact on loan repayment rates, which means that MFIs are relatively resistant to shocks that occur at the level of a country. Other study is Ahlin et al. (2011) which show MFI able to cover cost in high growth countries while higher workforce growth motivate lower slower pace of MFI outreach.

In addition, the existence of competition also increases the likelihood of worsening returns from $\mathrm{MFI}$ customers. This condition occurs because MFI borrowers get loan offers in more than one place, as a result the borrower takes both loans and ultimately affects the repayment ability of the MFI borrower. If this is continued, this condition can endanger the borrower's finances due to an increase in the debt ratio of the borrower to the level of ability to repay. Furthermore, overall MFI performance will also deteriorate. Hermes \& Hudon (2018) also shows other impacts of financial sector progress on MFI performance. According to Hermes \& Hudon (2018), the development of the financial sector also increases MFIs' access to financial services. One example is that MFIs can get financing from commercial banks in the form of linkage programs (Hamada, 2010). Hamada (2010)) found that financing from commercial banks increases the financing channelled by BPRs to the poor.

Financial sector development is defined as changes in the characteristics of the financial sector in a country over time (Hermes et al., 2009). The financial system consists of financial institutions such as commercial banks, development banks, capital markets, pension funds and so on. Apart from these institutions, the financial system also consists of institutions in charge of regulating and supervising financial institutions in a country, such as the central bank. In addition, the financial system also includes stocks and bonds listed in a country. 
An early empirical study by Hermes et al. (2009) show that better financial sector may motivate MFI to be more efficient. This may be the impact of spillover effect. While Ahlin et al. (2011) confirm this result and reveal that strong financial sector give rise to lower portfolio default and operational cost.

Market-failure hypothesis may explain the relationship between financial sector development and MFI performance (Vanroose \& D'Espallier, 2013). Market-failure hypothesis state that MFI fill the gap that commercial banks cannot fulfill. Their finding implies market failure hypothesis. MFI compete with commercial bank where a well-developed financial development push down MFI financial performance and motivate in searching for poorer customer (Vanroose \& D'Espallier, 2013). Prior studies have observed the relationship between financial sector and MFI performance. These studies present an inconsistent result. Those, we recommend following hypothesis as follows.

$\mathrm{H}_{1}$ : there is a relationship between financial sector development and MFI social \& financial performance

\section{RESEARCH METHOD}

This study is a quantitative study. This research object is uses financial data available on MixMarket. The population is all MFIs registered in MixMarket. This study uses purposive sampling with criteria MFI that have a complete required data from 1999 until 2019. Thus the research sample amounted to $347 \mathrm{MFIs}$. This study uses secondary data in the form of reporting for the 1999 and 2019 period. The advantage of the MixMarket data is this site covers all MFls in the world, but the weakness is the reports are voluntary.

The study uses an unbalanced panel data since it utilizes MFIs from nine countries but different years. There are two models which are social performance model and financial performance model. The empirical model is as follow.

$$
\operatorname{Per}_{i, j, t}=\propto_{0}+\propto_{1} \text { FD }_{j, t}+\propto_{2} \text { Aset }_{i, j, t}+\propto_{3} \text { Par30days }_{i, j, t}+\varepsilon_{i}
$$

$\operatorname{Per}_{i, j, t}$ is social and financial performance of MFI $i$, at country $j$, at time $t$. Social performance is average loan size (ALS) and financial performance is Operational Self-Sufficiency (OSS). $F D_{j, t}$ is financial development of country $j$ at time $t$ measure by total private credit to GDP. Aset $_{i, j, t}$ is log asset of MFI $i$ at country $j$ at time $t$. Par30 days $s_{i, j, t}$ is late payment portfolio for more than 30 days (Portfolio at risk) for $\mathrm{MFI} i$, in country $t$ at time $t . \varepsilon_{i}$ is error term

Table 1 display number of MFI from every country in Southeast Asia. There are 1.340 firm-year observation. 
Chaerani Nisa: Interaction Between Financial ...

Table 1. Total Number of MFls

\begin{tabular}{lc}
\hline \multicolumn{1}{c}{ Country } & Number of MFI \\
\hline Cambodia & 21 \\
East Timor & 3 \\
Indonesia & 71 \\
Laos & 5 \\
Myanmar & 13 \\
Philippine & 105 \\
Thailand & 1 \\
Vietnam & 36 \\
Total & 256 \\
\hline
\end{tabular}

Source: MixMarket

\section{RESULT AND DISCUSSION}

Table 2 present statistic descriptive for the data. The results of descriptive statistics show that the average OSS value or the ability of MFIs to cover operational costs by using their income is quite good. The average OSS value is 1,2 , which means that MFI can cover operational costs from its ability to generate profits. A value above 1 indicates that all operating costs have been covered from the income generated. In fact, MFIs able to generate more than the costs incurred so that the MFI can earn a profit which can then be used by the MFI for investment or other purposes.

PAR 30 describes the amount of loans that have not been repaid for more than 30 days. The assessment of more than 30 days is relatively more stringent than the other assessments because in general, banks use the benchmark for more than 90 days. Although using an assessment with a more conservative categorization, the PAR value of 30 days on MFI in Southeast Asia shows a low value of, which is $0,07 \%$.

ALS is the average loan size, or the average loan disbursed to borrowers. In this study, the average disbursed loan was further divided by the value of Gross National Income per capita to anticipate differences in GNI per capita from each country. The average ALS value is $0,55 \%$. This value is relatively small, this prompts MFIs to serve many poor customers so that their need for loans is also relatively low.

The value of private credit to GDP shows an average of $38 \%$. This figure shows that the average credit extended for each country included in this study was $38 \%$ of their Gross Domestic Product. On the asset side, there is a fairly large difference, this is also indicated by a high standard deviation value. Basically, MFIs are institutions that provide loans in small amounts, but that does not mean that MFIs cannot grow into institutions with large assets. This condition can be seen from the maximum asset of MFIs is USD 6 billion, although on the other hand there are MFIs with assets of only USD 448. Meanwhile, the average value of MFI assets in Southeast Asia is USD 48 million. 
Table 2. Descriptive Statistic

\begin{tabular}{lrrrrr}
\hline \multicolumn{1}{c}{ Variabel } & \multicolumn{1}{c}{ Obs } & \multicolumn{1}{c}{ Mean } & \multicolumn{1}{c}{ Std. Devi } & \multicolumn{1}{c}{ Min } & \multicolumn{1}{c}{ Max } \\
\hline OSS & 1.340 & 1,204 & 0,331 & $-0,427$ & 4,385 \\
Par30days & 1.340 & 0,069 & 0,104 & 0 & 1 \\
ALS & 1.340 & 0,561 & 1,174 & 0 & 14,426 \\
FD & 1.340 & 38,715 & 27,37602 & 2,113 & 133,136 \\
Asset & 1.340 & 48.784 .920 & 242.649 .698 & 448 & 6.129 .734 .396 \\
\hline
\end{tabular}

Table 3 demonstrate the correlation between social performance and financial performance. The positive correlation results indicate that there is trade off between social performance and financial performance. Which means that when MFI reaches more poor people, their ability to generate income is decreasing. This finding is in line with Reichert (2018) who conclude from the meta-analysis study that measurement using the depth of reach tends to find that there is a trade off between financial performance and social performance.

Table 3. Trade Off Between Social and Financial Performance

\begin{tabular}{ccc}
\hline \multicolumn{3}{c}{ Correlation Between Social and Financial Performance } \\
\hline & OSS & ALS \\
\hline OSS & 1,000 & 0,099 \\
ALS & 0,099 & 1,000 \\
\hline
\end{tabular}

Table 4 is the process of selecting a panel model using the Chow Test and Hausman Test. The use of the Chow Test aims to choose between the Pooled Least Square or the Fixed Effect Model. The Chow Test results show a Prob> F value of 0,000 , which means rejecting the hypothesis that all coefficients in each observed group are the same. Thus, the model used in this study is the Fixed Effect Model.

Table 4. Chow Test and Hausman Test

\begin{tabular}{llllll}
\hline & & \multicolumn{2}{c}{ Indicator } & \multicolumn{1}{c}{ Value } & Result \\
\hline Financial & Chow Test & F Test that all & P Value $=0,000$ & Fixed Effect \\
Performance & & intercept equal 0 & & \\
& Hausman Test & Chi Square & P value $=0,000$ & Fixed Effect \\
Social & Chow Test & F Test that all P Value $=0,000$ & Fixed Effect \\
Performance & intercept equal 0 & & \\
& Hausman Test & Chi Square & P value $=0,000$ & Fixed Effect \\
\hline
\end{tabular}

Furthermore, the selection between the Fixed Effect Model and the Random Effect Model. For the selection between the two models the Hausman Test will be used. The Hausman Test tests whether the difference is in the systematic coefficient or not. Failure to accept $\mathrm{H}_{0}$ indicates that the difference in coefficients is systematic. Based on this result, the model used in this study is the Fixed Effect Model. 
Chaerani Nisa: Interaction Between Financial ...

Table 5. Autocorrelation and Heteroskedasticity Test

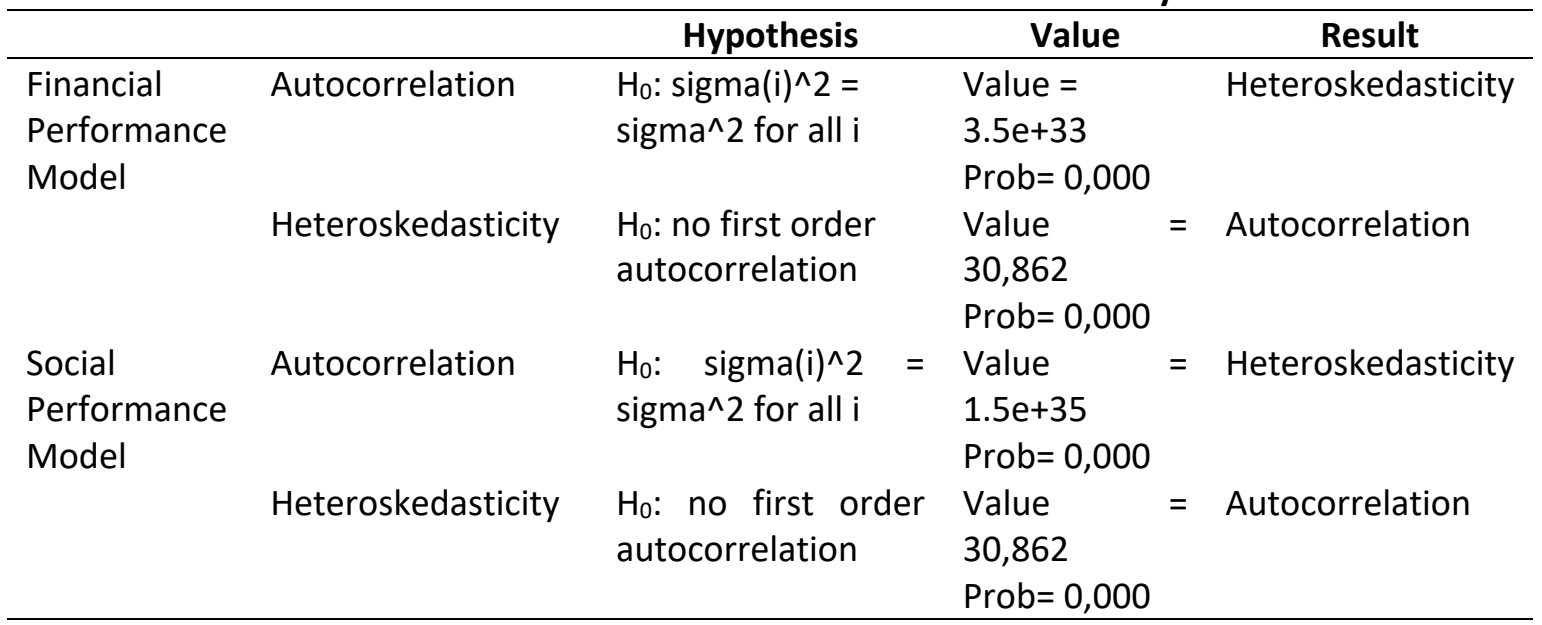

Table 5 exhibit results from the classical assumption test. It shows that the resulting model rejects Ho for both heteroscedasticity and autocorrelation testing. Thus, the model will be modified so that both assumptions are not violated. Hereby, the study uses Driscoll-Kraay estimator.

Table 6 Regression Result

\begin{tabular}{lrr}
\hline \multicolumn{3}{c}{ Dependent Variable } \\
\hline FD & \multicolumn{2}{c}{ OSS } \\
\hline \multirow{2}{*}{ Asset } & $-0,002^{*}$ & $0,016^{* * *}$ \\
& $(-1,890)$ & $(4,890)$ \\
Par30days & $0,056^{* * *}$ & $0,068^{* *}$ \\
& $(5,410)$ & $(2,500)$ \\
Intercept & $-0,207^{* *}$ & $-0,417^{* *}$ \\
Observations & $(-2,530)$ & $(-2,570)$ \\
Number of MFIs & 0,418 & $-1,084$ \\
within $\mathrm{R}^{2}$ & 1,340 & 1,340 \\
\hline Appendi & 256 & 256 \\
\end{tabular}

Appendix $*, * *$ and $* * *$ indicate significance in $10 \%, 5 \%$ and $1 \%$.

Table 6 shows the regression results of the financial performance model using the Driscoll-Kraay estimation model. The regression results show that private credit has a negative impact on the sustainability of MFIs, which means that the more advanced the banking sector in a country is, the worse its ability to survive will be. This can be seen from the smaller OSS value when banks increase their lending. This shows that there is competition between the two, namely when banks are quite advanced in terms of their high level of credit deployment, this has a negative impact on the financial performance of MFIs. Similar conditions are also found in Vanroose \& D'Espallier (2013). Vanroose \& D'Espallier (2013) see that the positive impact of the spill over effect is eliminated because of the negative impact of competition, MFIs must look for poorer customers and lower interest rates so that it gives impact on the level of costs and benefits. This decline in performance ultimately has a negative impact on the MFI's ability to survive.

On the other hand, this condition also reflects the existence of a market failure hypothesis, a condition in which MFIs serve customers who are not served by the traditional financial sector. The 
explanation is that when conditions in the traditional financial sector are poor, MFIs' ability to survive is good. This is possible because when the banking sector is bad, MFIs serve customers who are not served by commercial banks. In the end, MFIs can get bigger profits and reduce costs. Thus, the negative impact is not always bad if the country's conditions are not sufficiently developed.

However, these findings differ from those of Ahlin et al., (2011) and Hermes et al. (2009) where both found that progress in the financial sector actually had a positive impact on the financial performance of MFIs, although in Ahlin et al. (2011) the resulting correlation is not significant. Based on this explanation, it can be concluded that in MFls in Southeast Asia the conditions referred to as Vanroose \& D'Espallier (2013).

Table 6 also shows the results of the regression between loans and the average loan disbursed. The findings show that the increase in private credit in MFIs in the Southeast Asian region has a negative impact on the outreach of MFIs to the poor, this can be seen from the positive relationship between the ratio of credit to the average loan. This finding differs from the findings of Vanroose \& D'Espallier (2013) but resembles the findings of Ahlin et al. (2011) where they find that the credit ratio is positively related to the loan growth. This finding also reinforces the findings on the correlation between credit and the sustainability of previous MFIs. The finding of a negative correlation indicates the possibility of competition. The competition might come from the downscaling of commercial bank and reach MFI clients.

As we know that MFIs in Asia have different characteristics compared to MFIs in other regions that are generally distinguished from institutional missions which are mainly related to the economic development of communities so that they place more emphasis on social outreach to marginalized communities. The microfinance sector in Asia was established to provide financial services to the poor who have been marginalized from conventional financial services.

MFIs mostly grow in Asia, where most of the world's population resides in this region, with a high number of people living below the poverty line. The high number of poor people indicates the great need for MFI services which this condition has often been neglected. Therefore, this study focuses on the Asian region because specific observations on it can provide insights into factors that can improve MFI performance and ultimately improve services to the poor.

Meanwhile, the positive relationship between the ratio of credit and loans disbursed shows that when the financial sector improves, MFIs tend to offer larger loans. This condition is similar with (McIntosh et al., 2005), when competition increases, MFIs tend to channel loans to richer communities, which can be seen from a higher average loan. Thus, these findings support the argument that competition causes MFIs to target richer clients.

Whereas in the control variable, similar results were found both in the asset proxy of the MFI size or in par30days which is a proxy for non-performing loans. The measure is directly proportional to the MFI's sustainability level, which means that the bigger the MFI, the better its ability to generate income to cover its operational costs. Likewise, for social performance, the larger the size of the MFI, the greater the average loan disbursed. This shows that bigger MFIs also disburse larger loan size. This finding contrasts with Churchill (2019) which find that the greater the MFI the higher the outreach. It shows that regulator should give more space for bigger MFI to train small MFI.

Meanwhile, the correlation between loan quality and OSS and the average loan showed a negative relationship. This finding shows that the higher non-performing, the lower MFIs' sustainability. On the outreach side, MFIs with high non-performing loans have a negative impact on their ability to reach the poor. 


\section{CONCLUSION}

Financial sector development has a negative impact on the financial performance of MFIs. This can mean two things. First, the more developed financial sector is, the MFIs cannot run their business properly because the traditional financial sector acts as a competitor to MFIs. As a result, MFIs must either find poorer customers or lower interest rates. Second, when the financial sector does not develop properly, MFI fills the gap, thus the market failure hypothesis occurs in MFI. A well-developed financial sector bring positive impact on the average rate of loans disbursed. These findings show that the more advanced banking conditions in Southeast Asian countries, the larger the average loan disbursed. This is in line with Vogelgesang (2003) who sees that when MFIs face competition, they tend to provide larger loans.

The implication from this research is that regulators on MFIs in Southeast Asia should pay more attention to the relationship between the traditional financial sector and MFIs. Because there is a high probability that there will be friction between the two, so it is possible that it will have an impact on the ability of MFIs to run their business. Such as Xu et al. (2016) stated that MFIs suffer from downscaling effect from commercial bank, so they have to upscaling in order to survive. Regulator should pay more attention on separation between commercial bank and MFI target market.

\section{REFERENCE}

Ahlin, C., Lin, J., \& Maio, M. (2011). Where does microfinance flourish? Microfinance institution performance in macroeconomic context. Journal of Development Economics, 95(2), 105-120. https://doi.org/10.1016/j.jdeveco.2010.04.004

Churchill, S. A. (2019). The macroeconomy and microfinance outreach: a panel data analysis. Applied Economics, 51(21), 2266-2274. https://doi.org/10.1080/00036846.2018.1540857

Cull, R., Demirgüç-Kunt, A., \& Morduch, J. (2009). Microfinance meets the market. Journal of Economic Perspectives, 23(1), 167-192. https://doi.org/10.1257/jep.23.1.167

Deb, J. (2018). Competition and Commercialisation of Microfinance Institutions: Implications for the Sector. International Journal of Business Ethics and Developing Economies, 7(2), 27-36.

Evans, E., Opoku, O., Ibrahim, M., Sare, Y. A. (2019). The causal relationship between financial development and economic growth in Africa. International Review of Applied Economics, 33(6), 789-812. https://doi.org/10.1080/02692171.2019.1607264

Gonzalez, A. (2011). Resilience of Microfinance Institutions to National Macroeconomic Events: An Econometric Analysis of MFI Asset Quality. SSRN Electronic Journal, (Mix). https://doi.org/10.2139/ssrn.1004568

Hamada, M. (2010). Commercialization of microfinance in indonesia: The shortage of funds and the linkage program. Developing Economies, 48(1), 156-176. https://doi.org/10.1111/j.17461049.2010.00102.x

Hermes, N., \& Hudon, M. (2018). Determinants of The Performance of Microfinance Institutions: A Systematic Review. Journal of Economic Surveys, 32(5), 1483-1513. https://doi.org/10.1111/joes.12290

Hermes, N., Lensink, R., \& Meesters, A. (2009). Financial Development and the Efficiency of Microfinance Institutions. Groeningen.

Hermes, N., Lensink, R., \& Meesters, A. (2011). Outreach and Efficiency of Microfinance Institutions. World Development, 39(6), 938-948. https://doi.org/10.1016/j.worlddev.2009.10.018

Iqbal, S., Nawaz, A., \& Ehsan, S. (2019). Financial performance and corporate governance in microfinance: Evidence from Asia. Journal of Asian Economics, 60, 1-13. https://doi.org/10.1016/j.asieco.2018.10.002

McIntosh, C., Dejanvry, A., \& Sadoulet, E. (2005). How Rising Competition among Microfinance 
Institutions Affects Incumbent Lenders. The Economic Journal, 115(506), 987-1004.

Mersland, R., \& Øystein Strøm, R. (2009). Performance and governance in microfinance institutions. Journal of Banking and Finance, 33(4), 662-669. https://doi.org/10.1016/j.jbankfin.2008.11.009

Rahman, A., Khan, M. A., \& Charfeddine, L. (2020). Financial development-economic growth nexus in Pakistan: new evidence from the Markov switching model. Cogent Economics and Finance, 8(1). https://doi.org/10.1080/23322039.2020.1716446

Reed, L. R. (2015). Mapping Pathways out of Poverty. Microedit Summit Campaign.

Reichert, P. (2018). A meta-analysis examining the nature of trade-offs in microfinance. Oxford Development Studies, 46(3), 430-452. https://doi.org/10.1080/13600818.2018.1427223

Vanroose, A., \& D'Espallier, B. (2013). Do microfinance institutions accomplish their mission? Evidence from the relationship between traditional financial sector development and microfinance institutions' outreach and performance. Applied Economics, 45(15), 1965-1982. https://doi.org/10.1080/00036846.2011.641932

Vogelgesang, U. (2003). Microfinance in times of crisis: The effects of competition, rising indebtedness, and economic crisis on repayment behavior. World Development, 31(12), 2085-2114. https://doi.org/10.1016/j.worlddev.2003.09.004

Xu, S., Copestake, J., \& Peng, X. (2016). Microfinance Institutions' Mission Drift in Macroeconomic Context. Journal of International Development, 28(1), 1123-1137. https://doi.org/10.1002/jid 
